\title{
Ethnopharmacological application of chamomile (Matricaria chamomilla L.) in the Pirot County of Southeastern Serbia
}

\author{
Marija Marković ${ }^{1 *}$, Dejan Pljevljakušić ${ }^{2}$, Ksenija Kojičić ${ }^{3}$, \\ Snežana Cupara ${ }^{3}$ \\ ${ }^{1}$ University of Niš - Faculty of Science and Mathematics, Department of Biology and \\ Ecology, Višegradska 33, 18000 Niš, Republic of Serbia \\ ${ }^{2}$ Institute for the study of medical plants „Dr. Josif Pančić”, Tadeuša Koščuška 1, 11000 \\ Beograd, Republic of Serbia \\ ${ }^{3}$ University of Kragujevac - Faculty of Medical Sciences, Department of Pharmacy, \\ Svetozara Markovića 69, 34000 Kragujevac, Republic of Serbia
}

*Corresponding author: dr Marija Marković, E-mail: marijam@pmf.ni.ac.rs

\section{Summary}

Chamomile (Matricaria chamomilla L.) is a herbaceous plant from family Astereaceae, that has a long history of use in traditional medicine. The first written report of chamomile was found in Ancient Egypt: crushed chamomile flower-heads were used to relieve skin inflammation, prevent dermatitis, and in cosmetic preparations. The subject of this study was to examine the ethnopharmacological application of chamomile in the Pirot County of Serbia. The study was conducted in the form of a population survey on the population of four municipalities: Pirot, Babušnica, Bela Palanka, and Dimitrovgrad. This study shows that chamomile has been one of the ten best known medicinal plant species in Pirot County. The most common way of the application was a herbal tea for oral use against cold, stomach diseases, throat infection, and mild sedation. Externally, in the form of compresses, it has been used against eye swelling, skin inflammation, and infections, while the oily form was used in the treatment of wounds and burns.

Key words: chamomile, medicinal plant, Pirot County. 


\section{Introduction}

Herbal medicinal products can be used as a useful complement to modern pharmacotherapy or disease management, in which safety is based on the experience gained through years of use in traditional medicine (1). Medicinal plants have been found to constitute on average $10 \%$ of the total flora of Serbia (2). Plant parts contain various compounds with medicinal properties. Therefore, herbal drugs have been considered as a raw material in drug production.

Pirot County in southeastern Serbia includes the region that comprehends the following municipalities: Babušica, Bela Palanka, Dimitrovgrad, and Pirot evaluated as a source of medicinal plants (3-8).

Chamomile (Matricaria chamomilla L., synonym: Matricaria recutita L.) is an annual plant of the Asteraceae family that is about 10 to $60 \mathrm{~cm}$ tall, has a thin, spindly, branched root and an upright stem, that is most commonly branching. The leaves are alternate, many times finely divided. The flower heads are heterogamous, with handles. The central flowers are tubular, golden yellow, and the outer flowers are white. It blooms in May and September (9). It contains a valuable essential oil, but also flavonoids, coumarins, and other compounds $(7,8)$.

The first written reports on the use of chamomile were in Ancient Egypt. It was used to relieve skin inflammation, prevent dermatitis, and as an ingredient in cosmetic products. Ancient Egyptians used chamomile not only for treatment but also in religious practices and for embalming dead bodies (10).

The chamomile flower-heads (Chamomilae flos) have been used internally or externally in the Serbian folk medicine $(8,11)$. The chamomile flower-heads have been used internally for disorders of the digestive organs (gastritis, enteritis, colitis, bloating, cramps, diarrhea, dyspepsia), as well as in the treatment of hemorrhoids, irregular menstrual cycle or mastitis. External use involves the treatment of various skin and mucous membrane inflammations (11), irrigation of ulcers, wounds, burns, or eczema (12). Chamomile flower-heads may cause a cross-allergic reaction to the people otherwise allergic to any of the Asteraceae species $(8,12)$. A frequent use during pregnancy and lactation should be avoided (12).

Chamomile essential oil, as well as its isolated compounds, show antiphlogistic effect, due to which they have been used in the treatment of inflammatory skin and mucosa processes of different etiology. Besides, chamomile essential oil shows fungistatic and fungicidal action against various dermatophytes (13). The antiseptic properties and anti-inflammatory effects of chamomile have also been confirmed by the latest scientific research $(10,14)$. According to European Union herbal monograph on Matricaria recutita L., flos, there are five indications in traditional use 1) gastro-intestinal complaints such as bloating and minor spasms, 2) common cold, 3) minor ulcers and 
inflammations of the minor mouth and throat, 4) irritations of skin and mucosae in the anal and genital region, 5) inflammation of the skin (sunburn), superficial wounds and small boils (furuncles) (15).

This study evaluates the common traditional use of chamomile in ethnomedicine and ethnoveterinary medicine and it was conducted as a population survey in Pirot County. The presented data may help to focus on future chemical and pharmacological research in the development of new pharmaceutical preparations against human or domestic animal diseases.

\section{Methodology}

The population of the rural areas belonging to the municipalities of Pirot, Babušnica, Bela Palanka, and Dimitrovgrad completed a questionnaire, which contained general data on respondents and specific questions, related to the knowledge and manner of medicinal plants' administration. The population of 144 villages of the Pirot County was included. A total of 631 people were interviewed, 337 of which were male and 294 were female $(1,2)$. The results of the surveys have been listed with ethnomedical data, that include the form in which the medicinal plant has been used and the actual use of a medicinal plant in human (Table I,III) and veterinary (Table II) ethnomedicine.

\section{Results and Discussion}

The species Matricaria chamomilla has been known among the local population of the Pirot County by the names: bela rada, podrumče, titrica, and kamilica. A total of 383 participants reported that chamomile was a medicinal species, while 380 of these participants mentioned its use in human ethnomedicine and only four people in ethnoveterinary medicine. One of them reported that chamomile was used in both human and veterinary ethnomedicine. 
Table I Frequency of reported indications and forms of application for the traditional use of chamomile in human ethnomedicine in Pirot County.

Tabela I Učestalost prijavljenih indikacija i oblici primene za tradicionalnu upotrebu kamilice u ljudi u Pirotskom okrugu.

\begin{tabular}{lccccc}
\hline \multicolumn{1}{c}{ Indication } & Pirot & Babušnica & $\begin{array}{c}\text { Bela } \\
\text { Palanka }\end{array}$ & Dimitrovgrad & Total \\
\hline cold & 71 & 25 & 32 & 15 & 143 \\
stomach diseases & 42 & 15 & 13 & 9 & 79 \\
sore throat & 17 & 5 & 10 & 2 & 35 \\
gargle & 14 & 2 & 8 & 3 & 26 \\
eyewash & 11 & 5 & 5 & 1 & 16 \\
sedation & 8 & 3 & 4 & 1 & 16 \\
inflammation & 8 & 2 & 6 & 0 & 13 \\
cough & 6 & 2 & 4 & 3 & 4 \\
skin problems & 0 & 1 & 3 & & 24 \\
other & 12 & 4 & 5 & 35 & 371 \\
Form of application & 187 & & 87 & 1 & 7 \\
herbal tea & 3 & 62 & 2 & 0 & 1 \\
compress & 0 & 1 & 0 & & \\
oil & & 1 & & & \\
\hline
\end{tabular}

Table II Awareness of chamomile (Matricaria chamomilla L.) use in ethnoveterinary medicine in the Pirot County - overview.

Tabela II Korišćenje kamilice (Matricaria chamomilla L.) u etnoveterinarskoj medicini u Pirotskom okrugu - pregled

\begin{tabular}{lllcccl}
\hline Municipality & The village & Nationality & Gender & Age & Form & Use \\
\hline Pirot & Dojkinci & Srb. & F & 69 & tea & stomach problems \\
Bela Palanka & Čiflik & Srb. & F & 31 & tea & cold \\
Dimitrovgrad & Željuša & Bug. & F & 49 & tea & cold \\
Dimitrovgrad & Željuša & Bug. & F & 49 & tea & stomach problems \\
\hline
\end{tabular}

The largest number of participants confirmed the use of chamomile in the form of tea against colds (143 subjects) and stomach problems and different stomach diseases (79 subjects). Many participants confirmed its use against throat infections (34 subjects), while 29 subjects specified the use as mouth and throat gargle, 25 of them mentioned mouth gargling (14) or throat gargling (11). Four participants emphasized specific external use: gargling of gums (1), tooth inflammation lavage (1), throat infection lavage (1) inflammation of the gums lavage (1). A total of 19 people mentioned the use of 
chamomile for eyewash, 16 people mentioned the use for sedation, and 13 people mentioned the use against coughing (Table III).

Table III Therapeutic groups with frequency of reported indications of application for traditional use of chamomile in four municipalities in Pirot County.

Tabela III Učestalost prijavljenih indikacija za tradicionalnu upotrebu kamilice po organskim sistemima u četiri opštine Pirotskog okruga

\begin{tabular}{|c|c|c|c|c|c|}
\hline $\begin{array}{l}\text { Therapeutic } \\
\text { group }\end{array}$ & Indication & Pirot & Babušnica & $\begin{array}{c}\text { Bela } \\
\text { Palanka }\end{array}$ & Dimitrovgrad \\
\hline \multirow[t]{4}{*}{ Respiratory } & cold & 71 & 25 & 32 & 15 \\
\hline & gargle & 14 & 2 & 7 & 2 \\
\hline & cough & 6 & 2 & 4 & 1 \\
\hline & sore throat & 18 & 5 & 10 & 2 \\
\hline \multirow[t]{4}{*}{ Digestive } & stomach diseases & 42 & 15 & 13 & 9 \\
\hline & diarrhea & 1 & - & - & - \\
\hline & digestion & - & - & 1 & - \\
\hline & $\begin{array}{l}\text { increased acid production in the } \\
\text { stomach }\end{array}$ & - & - & 1 & - \\
\hline \multirow{3}{*}{$\begin{array}{l}\text { Nervous } \\
\text { system }\end{array}$} & & & & & \\
\hline & sedation & 8 & 3 & 4 & 1 \\
\hline & insomnia & 1 & - & - & - \\
\hline \multirow[t]{8}{*}{ Inflammation } & eyewash & 7 & 5 & 5 & 2 \\
\hline & inflammation & 3 & 2 & 5 & - \\
\hline & eye inflammation & 3 & - & - & - \\
\hline & face wash & 2 & - & - & - \\
\hline & inflammation of the gums & 1 & - & - & - \\
\hline & rinsing of the oral cavity and gums & 1 & - & - & - \\
\hline & gargle (tooth inflamation) & - & - & 1 & - \\
\hline & mucosal inflammation & 1 & - & - & - \\
\hline \multirow{2}{*}{ Urinary } & bladder and kidney disease & - & - & - & 2 \\
\hline & diuretic & 1 & - & - & - \\
\hline \multirow[t]{2}{*}{ Infectious } & eye infection & 1 & - & - & - \\
\hline & influenza & - & - & - & 1 \\
\hline \multirow[t]{3}{*}{ Preventive } & disease prevention, coffee & & & & \\
\hline & replacement & 2 & - & - & - \\
\hline & strengthening the immune system & 1 & - & - & - \\
\hline \multirow[t]{7}{*}{ Dermatoilogy } & skin diseases & - & 1 & 1 & - \\
\hline & hair washing & 1 & - & - & - \\
\hline & vaginal flushing & 1 & - & - & - \\
\hline & wounds and burns & - & 1 & - & - \\
\hline & $\begin{array}{l}\text { fixing hair roots (balm for blond } \\
\text { hair) }\end{array}$ & - & - & 2 & - \\
\hline & for a nicer skin complexion & - & - & 2 & - \\
\hline & swelling of the eyes & - & - & - & 1 \\
\hline \multirow[t]{6}{*}{ Various } & lung diseases & - & 1 & 2 & - \\
\hline & unknown use & 1 & 1 & 1 & - \\
\hline & high temperature & 2 & - & - & - \\
\hline & detoxification & 1 & - & - & - \\
\hline & blood purification & - & 1 & - & - \\
\hline & nausea & - & - & - & 1 \\
\hline
\end{tabular}


The use of chamomile against various inflammations in the ethnomedicine of the Pirot County confirmed 9 people, while the use in the stomach diseases and eye inflammation was confirmed by 6 and 3 people, respectively. Not specifying the particular way of use, 3 people confirmed the chamomile use. Two people mentioned the use of chamomile tea as a face wash, in the prevention of various diseases, and also against bladder, kidney and skin diseases, against different stomach ailments, against fever, as a coffee replacement, use for strengthening the hair roots of light hair and for enhancing skin complexion (in the form of compress). One person mentioned the use of chamomile in the form of tea for blood cleansing, detoxification, vaginal lavage, strengthening of the immune system, against respiratory diseases, against influenza, against hyperacidity (elevated acid), against nausea, against insomnia, against lung disease, against diarrhea, against various infections, against inflammation of the mucous membranes, in urinary problems, hair washing and for enhanced digestion. Also, one person mentioned the use of chamomile in eye swelling treatment as well as against eye infection. One person mentioned using its oily form against wounds and burns.

A total of four participants in the Pirot County confirmed that chamomile was used as an infusion in ethnoveterinary medicine, two participants confirmed its use against colds and two participants confirmed its use against stomach problems in domestic animals (Table II).

We observed that our results are similar to the ones obtained in the ethnobotanical study on the medicinal use of chamomile in Serbian ethnomedicine by Dajić Stevanović et al. (2014) (16). They found that the population of Serbia used chamomile flower-heads in the form of tea against inflammation and spasms in the intestinal tract, coughs, bronchitis, fever, and colds, and externally against inflammation of the skin, larynx and pharynx inflammation, as well as wounds and burns. Jarić et al. (2017) provided similar data in the study of the different applications of medicinal plants growing on the mountain Kopaonik in Central Serbia (17). They referred to the chamomile as an antiseptic, antiinflammatory and sedative agent, specifying that its external use included treatment of skin and mucous membranes, burns, wounds, sores, and vaginal flushes. They confirmed its internal use in abdominal pain, dyspepsia, and constipation, as well as for inhalation during sinusitis. Zlatković and Bogosavljević (2014) analyzed the taxonomic and pharmacological evaluation of medicinal plants of the Svrljiški Timok canyon in eastern Serbia (18). They also referred to chamomile as an antiseptic, carminative, mild sedative, and antiphlogistic, against abdominal cramps, cough, bronchitis, fever and cold, inflammation of the skin, larynx and pharynx inflammation and against wounds and burns. Besides, Janaćković et al. (2019) in the most recent ethnobotanical study for eastern Serbia, in the Negotin Krajina, based on a survey of the local population, noted the use of chamomile against digestive disorders, vaginal problems and for eye rinsing 
(19). These authors reported also the use of chamomile flower-heads in the preparation of skin care products such as domestic creams and shampoos.

We found a similar ethnopharmacological application of chamomile in human ethnomedicine in Pirot County. The following seven therapeutical applications are different and new from well-known in Serbia 1) bladder and kidney disease (2 reports), 2) blood purification (1 report), 3) disease prevention, coffee replacement (2 reports), 4) diuretic (1 report), 5) detoxification (1 report), 6) lung diseases (3 reports) and 7) nausea (1 report).

In addition to the use of chamomile in ethnomedicine, during the population survey in the Pirot County, by four respondents, the use in ethnoveterinary against colds and stomach problems in domestic animals was also mentioned.

\section{Conclusion}

Based on the results of a population survey in the Pirot County, it was confirmed that chamomile has been often used in the traditional medicine of the rural population of this county as well as in other regions of Serbia. Chamomile flower-heads have been used most often in the form of herbal tea (infusion). The main internal indications were cold, cough, stomach, and digestive problems, sore throat, various body inflammations, and sedation. Externally, it was mainly used for mouth, throat, and face washes. Other uses included prevention of various diseases, coffee replacement, against bladder, kidney and skin diseases, fever, for the hair roots strengthening of the light hair and skin complexion enhancement. The most common way of the application was as a tea in a form of infusion for oral use, but also the infusion was used as compresses against the skin and mucous membrane inflammation, eye infection, and swelling, as well as oil in the treatment of wounds and burns. The main indications in the ethnoveterinary medicine were colds and digestive ailments of domestic animals.

\section{Acknowledgment}

The authors would like to express gratitude to the Ministry of Education and Science of the Republic of Serbia: Contract No. 451-03-68/2020-14/ 200003 and Grant No. 175014. 


\section{Literature}

1. Marković M. Upotreba hajdučke trave u etnomedicini Pirotskog okruga (jugoistočna Srbija) (Application of yarrow (Achillea millefolium L.) in ethnomedicine of the Pirot County (southeastern Serbia)). Arh farm. 2019; 69:839-859.

2. Stankov Jovanović V, Šmelcerović A, Smiljić M, Ilić M, Marković M. Ethnopharmacological application of St. John's wort in Pirot county (Etnofarmakološka primena kantariona u Pirotskom okrugu), Pirotski zbornik. 2018;43:141-6.

3. Mihajlov M, Milojević B. Farmakognozijska karta okoline Pirota. Zbornik radova Simpozijuma „Stogodišnjica Flore okoline Niša”, Univerzitet u Nišu, Tehnološki fakultet u Leskovcu. Podružnica Srpskog biološkog društva, Niš. 1985; 145-55.

4. Milojević B, Mihajlov M. Narodna terminologija lekovitog bilja u okolini Pirota. Zbornik radova Simpozijuma „Stogodišnjica Flore okoline Niša, Univerzitet u Nišu, Tehnološki fakultet u Leskovcu. Podružnica Srpskog biološkog društva, Niš. 1985; 167-80.

5. Ranđelović N, Sotirov S, Stamenković V, Redžepi F, Ranđelović V, Zlatković B. Lekovito bilje subregiona Pirot. Zbornik radova Tehnološkog fakulteta u Leskovcu, 1991;7/8:29-33.

6. Marković M., Pavlović-Muratspahić D., Matović M., Marković A, Stankov-Jovanović V. Aromatic Flora of the Vidlič Mountain. Biotechnol Biotec Eq. 2009;23(2):1225-9.

7. Marković M, Matović M, Pavlović D, Zlatković B, Marković A, Jotić B, Stankov-Jovanović V. Resources of medicinal plants and herbs collector's calendar of Pirot County (Serbia). Biologica Nyssana. 2010;1(1-2):9-21.

8. Marković M, Rakonjac Lj, Nikolić B. Lekovito bilje Pirotskog okruga. Beograd: Institut za šumarstvo; 2020. $173 \mathrm{p}$.

9. Gajić M. Rod Matricaria L. In: Josifović M., editor. Flora SR Srbije VII: Srpska akademija nauka i umetnosti, Odeljenje prirodno-matematičkih nauka, Beograd; 1975; p. 110-3.

10. Sharifi-Rad M, Nazaruk J, Polito L, Morais-Braga BFM, Rocha EJ, Coutinho MDH. et al. Matricaria genus as a source of antimicrobial agents: From farm to pharmacy and food applications. Microbiol Res. 2018;215: 76-88. DOI: 10.1016/j.micres.2018.06.010.

11. Sarić M. Matricaria chamomilla L. In: Sarić M. editor. Lekovite biljke SR Srbije. Beograd: Srpska akademija nauka i umetnosti, Odeljenje prirodno-matematičkih nauka, Posebna izdanja, Vol. DXCVIII, No. 65; 1989; p. 359-61.

12. Tasić S, Šavikin Fodulović K, Menković N. Vodič kroz svet lekovitog bilja. Beograd: Samostalno izdanje. $98 \mathrm{p}$.

13. Jančić R, Stošić D, Mimica-Dukić N, Lakušić B. Aromatične biljke Srbije, Beograd - Gornji Milanovac: NIP Dečje novine; 1995; p. 263-5.

14. Shoara R, Hashempur MH, Ashraf A, Selehi A, Dehshshri S, Habibagahi Z. Efficacy and safety of topical Matricaria chamomilla L. (chamomile) oil for knee osteoarthritis: a randomized controlled clinical trial. Complementary Therapies in Clinical Practice 2015; 21:181-7. 
15. Europaean Medicines Agency, Science Medicine Health. Committee on Herbal Medicinal Products (HMPC). European Union herbal monograph on Matricaria recutita L., flos.; 2015, 7 July. EMA/HMPC/55843/2011 https://www.ema.europa.eu/en/documents/herbal-monograph/finaleuropean-union-herbal-monograph-matricaria-recutita-l-flos_en.pdf

16. Dajić Stevanović Z, Petrović M, Aćić S. Ethnobotanical Knowledge and Traditional Use of Plants in Serbia in Relation to Sustainable Rural Development. In: Pieroni A, Quave C. editors. Ethnobotany and Biocultural Diversities in the Balkans. Springer, New York; 2014; p. 229-52.

17. Jarić S, Popović Z, Mačukanović-Jocić M, Đurđević L, Mijatović, L., Karadžić B. et al. An ethnobotanical study of the usage of wild medicinal herbs from Kopaonik Mountain (Central Serbia), J Ethnophalmacol 2017;111:160-75.

18. Zlatković B, Bogosavljević S. Taxonomic and pharmacological valorization of the medicinal flora in Svrljiški Timok gorge (Eastern Serbia). Facta Universitatis Series: Medicine and Biology 2014;16(2):76-86.

19. Janaćković P, Gavrilović M, Savić J, Marin P, Dajić Stevanović Z. Traditional knowledge of plant use from Negotin Krajina (Eastern Serbia): An ethnobotanical study, Indian J Tradit Know. 2019;18(1):25-33. 


\title{
Etnofarmakološka upotreba kamilice (Matricaria chamomilla L.) u Pirotskom okrugu u Jugoistočnoj Srbiji
}

\author{
Marija Marković ${ }^{1 *}$, Dejan Pljevljakušić², Ksenija Kojičić \\ Snežana Cupara ${ }^{3}$
${ }^{1}$ Univerzitet u Nišu - Prirodno-matematički fakultet, Departman za biologiju i ekologiju Višegradska 33, 18000 Niš, Republika Srbija
${ }^{2}$ Institut za proučavanje lekovitog bilja „Dr. Josif Pančić”, Tadeuša Koščuška 1, 11000
Beograd, Republika Srbija
${ }^{3}$ Univerzitet u Kragujevcu - Fakultet medicinskih nauka, Departman za farmaciju, Svetozara Markovića 69, 34000 Kragujevac, Republika Srbija

*Autor za korespondenciju: dr Marija Marković, E-mail: marijam@pmf.ni.ac.rs

\section{Kratak sadržaj}

Kamilica (Matricaria chamomilla L.) je zeljasta biljka iz familije Asteraceae, koja ima dugu istoriju upotrebe u tradicionalnoj medicini. Prvi pisani izveštaji o kamilici nalazi se u starom Egiptu: zdrobljeni cvetovi kamilice korišćeni su za ublažavanje upala kože, za sprečavanje dermatitisa i za izradu kozmetičkih preparata. Predmet ovog istraživanja bio je ispitati etnofarmakološku primenu kamilice u Pirotskom okrugu. Istraživanje je sprovedeno na osnovu anketiranja stanovništva u četiri opštine: Pirot, Babušnica, Bela Palanka i Dimitrovgrad. Zabeleženo je da je Matricaria chamomilla jedna od deset najpoznatijih lekovitih biljaka u okrugu. Najčešće se koristi u vidu čaja protiv prehlade i protiv stomačnih tegoba, protiv upale grla i za smirenje. U vidu obloga koristi se protiv upala, infekcije i otoka očiju, a u vidu ulja protiv rana i opekotina.

Ključne reči: kamilica, lekovita biljka, Pirotski okrug 